ISSN 1991- 8690

website: http:// jsci.utq.edu.iq

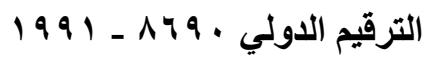

Email: utjsci@utq.edu.iq

\title{
Effect of Late Pregnancy, Parturition and Early Lactation on T3, T4and Cortisol Level of Heifers and Cows
}

\author{
Jassim .M.A.ALkalby Atheer Qassim Mohammad \\ Coll. Of Vet.Med- Univer. Of Basra \\ Department of physiology and pharmacology
}

\section{Summary}

The present study was carried out in the Al-Dujalah Cows Station which is located in Wasit governorate, Iraq. From 305 crossbred cows (Holstein x Friesian breeds), thirty six heifers (2.5-3.5) years old and thirty six multiparous cows (5-7) years old at different physiological conditions. The heifers and cows were divided into six equal groups depending on their physiological conditions as follows, group 1: Non-pregnant heifers (control), group 2: (Heifers in $7^{\text {th }}$ month of pregnancy), group 3: (Heifers in $8^{\text {th }}$ month of pregnancy), group 4: (Heifers in $9^{\text {th }}$ month of pregnancy), group 5: (Heifers at 1-4 hours of parturition), group 6: (Heifers in first month of lactation). The multiparous cows were divided as that of heifers.

The blood samples $(5 \mathrm{ml})$ were collected from Jugular vein at 2 weeks interval during pregnancy, at parturition (1-4 hours after parturition) and first month of lactation and deposited into plastic tube without anticoagulant to obtaining the serum samples for hormonal analysis.

The study revealed the following results: A significant increase $(\mathrm{p} \leq 0.05)$ in serum (T4) level was recorded in last month of pregnancy in both heifers and cows compared with control and other studied groups and a significant decrease in T3 level was observed in $7^{\text {th }}$ month of pregnancy, at parturition and first month of lactation in cows while there was a significant increase in T3 level was recorded in $9^{\text {th }}$ month of pregnancy in heifers compared with control and other studied groups.

A significant increase $(\mathrm{p} \leq 0.05)$ in serum cortisol level was recorded in first month lactating animals compared with control and other studied groups in both heifers and cows, and a significant increase in serum cortisol level was observed in control, $8^{\text {th }}$ and $9^{\text {th }}$ month of pregnancy and at parturition in cows compared with that of heifers.

Key words: Cows late Pregnancy, Parturition, Early Lactation, T4, T3, Cortiso 


\section{تأثير الفترة المتأخرة من الحمل ,وعند الولادة والمرحلة المبكرة من أنتاج الحليب على مستوى هورمونات الثايرونين ثلاثي اليود والدرقين والكورتيزول في الأباكير والأبقار}

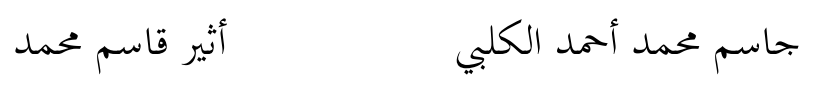

جامعة البصرة - كلية الطب البيطري - فرع الفسلجة والأدوية والكيمياء

أجلاصة الجريت الدراسة الحالية في محطة أبقار الدجيل الواقعة في محافظة واسط ومن مجموع ه.r من الأبقار المضربة (هولثتاين +فريزيان)

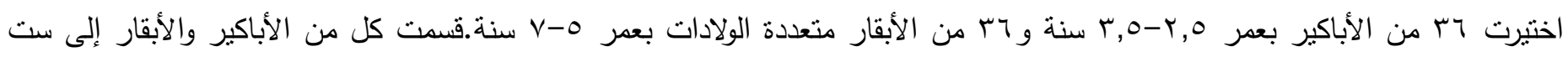

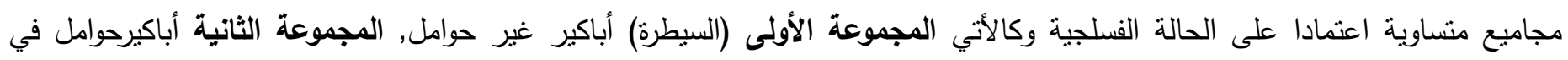

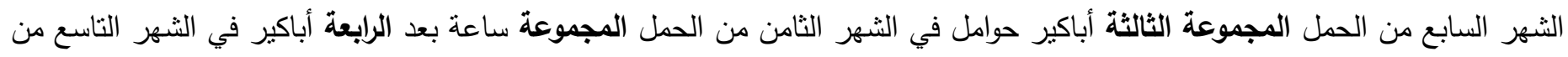

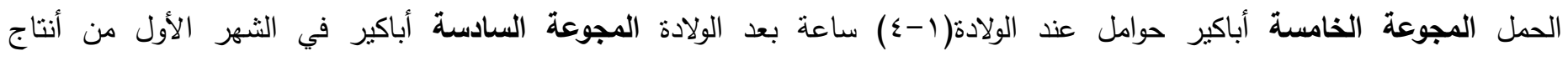

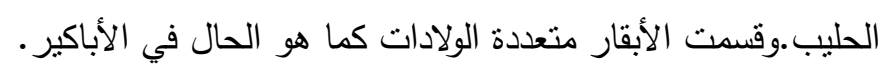

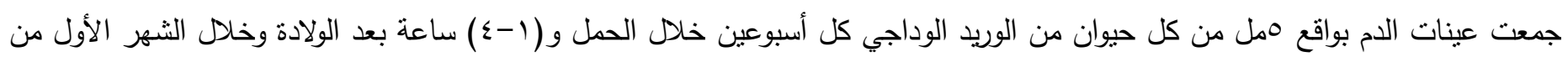

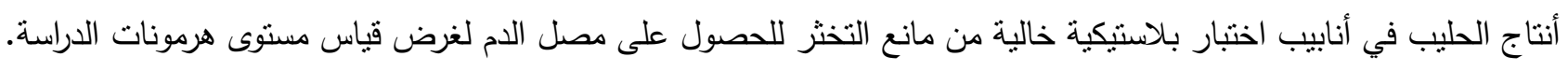

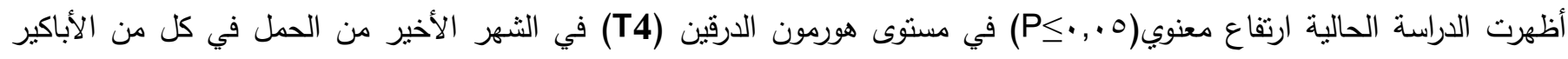

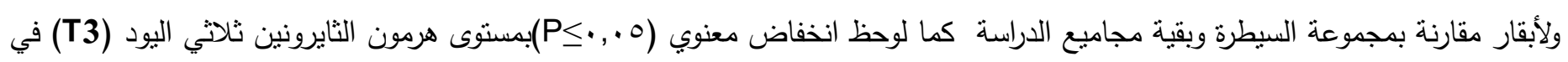

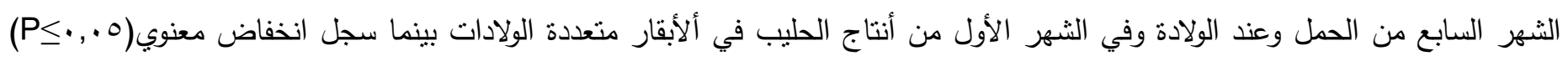

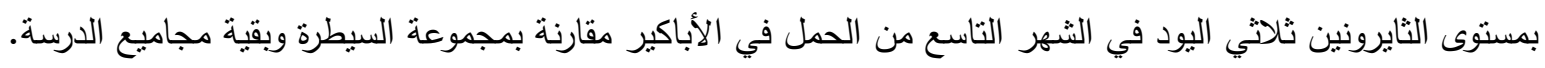

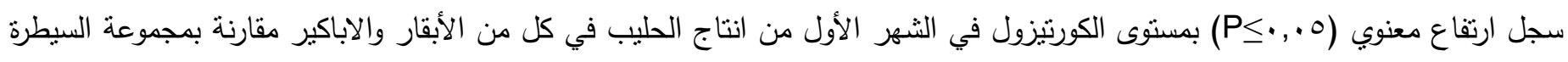

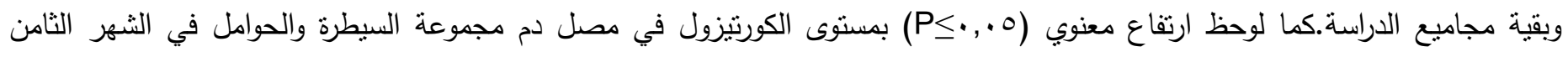

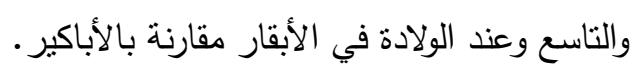

\section{Introduction}

Pregnant dairy cows are at a light risk of metabolic and reproductive disorders and oxidative stress is considered to be involved in these events (Turk et al., 2005). Pregnancy and lactation are physiological statuses considered to modify metabolism in animals (Krajnicakova et al. 2003; Iriadam, 2007).

The last 2-3 months of gravidity are extremely critical in cattle due to stress of pregnancy. The following deterimental factors may negatively influence pregnant breeding cows and therefore the fetus , qualitatively not fully valued feed ration ,shortened dry period and a number of health disturbances ( diarrhea , anemia , hepatodystrophy, ketosis, mastitis, acid-base balance disturbances, intrauterine infections ( Slanina et al. 1977 ) .The hormonal activity of thyroid gland has an important role in the transitional period for determining cell metabolism of lipid and carbohydrates and the lactation course itself by its thyroid hormones (Nikolic et al. 1997). Thyroid 
hormones, triiodthyronine (T3) and thyroxin (T4) have a major role in differentiation, growth and development of animals (Bani Ismail et al. 2009). Cortisol is a well-accepted indicator for stress in animals and man. The releases of adrenocorticotropic hormone from the pituitary gland occur in late pregnancy, (Kulbery et al. 2002). The cortisol values were varied according to pregnancy, parturition and lactation as stresses (Henze et al. 1994).

The present study is aimed to investigate the effect of late pregnancy, parturition and early lactation on some hormones level of crossbred cows and heifers.

\section{Materials and Methods}

\section{Experimental Animals:}

The present study was carried out in the AlDujalah cow's station (picture 1) which is located in Wasit governorate-Iraq, about 40 kilometers southeast of the city of AL-Kut. From 305 crossbred cows (Holestine X Friesian breeds), thirty six heifers and thirty six adult cows of different ages and physiological conditions were selected for this study. These cows were under the control of the veterinary health by veterinarians working at the station. Pregnancy was diagnosed based on the records of the station and to confirm the pregnancy and determine the age of the fetus, rectal palpation was used. All animals were maintained and housed under similar conditions of feeding and management. The animals were fed twice a day with green fodder and concentration mixture, and water was supplied ad libitum.

\section{Experimental Design:} follows:

The study included two experiments as

\section{The First Experiment}

Thirty six heifers, (2.5-3.5) years old were divided into 6 groups, 6 animals in each group. The grouping was done depending on their physiological conditions as follows:
1.Group1:non-pregnant heifers (control).

2. Group 2: pregnant heifers (in the 7th month of pregnancy).

3. Group 3: pregnant heifers (in the 8th month of pregnancy).

4. Group 4: pregnant heifers (in the 9th month of pregnancy).

5. Group 5: parturient heifers (1-4 hours after parturition).

6. Group 6: postpartum heifers in first month of lactation.

\section{The Second Experiment}

Thirty six adult multiparous cows (5-7) years old were divided into 6 equal groups. The grouping was done depending on their physiological conditions like that of the first experiment.

\section{Collection of Blood Samples}

All blood samples were collected between 810 hours am in order to standardize the time of collection which may affect certain blood parameters. Blood samples (5) ml were collected from jugular vein puncture at 2 weeks interval and at parturition during the experimental period from all animals. The collected blood from each animal deposited into tube without anticoagulant and allowed to clot at room temperature. Then the tubes were centrifuged at 3,000 rpm for 15 minute and the serum samples were stored at $-20^{\circ} \mathrm{c}$ until used for biochemical analysis.

\section{Total Triiodothyronine (T3) and Thyroxin (T4) Concentrations}

For determination of serum T3 and T4 level, Kit of (Monobind Inc. lake forest CA 92630, USA) was used.

\section{Cortisol hormone Concentration}

Jconcentration in serum or plasma by microplate enzyme immunoassay, kit of (Monobind Inc. lake forest CA 92630, USA) was used.

\section{Statistical analysis:}

Analysis was done using analysis of variance (one way ANOVA) through SPSS computer 
package version 11 . The differences are considered to be significant at $(\mathrm{p}<0.05)$, and the differences between means were done by LSD, (Steel\& Torrie, 1980). All data expressed throughout as mean $\pm \mathrm{SD}$.

\section{Results}

The results of the T3 levels are represented in Table (1). In heifers a significant increase $(p \leq 0.05)$ in T3 level was recorded in 9th month pregnant group compared with control and other studied groups and there was a significant decrease $(p \leq 0.05)$ in T3 level recorded in 7 th month pregnant, parturient and early lactating groups compared with control and other groups.

There was a significant decrease $(\mathrm{p} \leq 0.05)$ in $\mathrm{T} 3$ level of 7 th month pregnant, parturient and 1st month lactating cows compared with control.

No significant difference was observed between both heifer and cows in all studied reproductive stages.

Table (1): The serum (T3) hormone level ( $\mu \mathrm{g} / \mathrm{dl})$ in Heifers and cows during late pregnancy, parturition, and early lactation (Mean \pm SD)

\begin{tabular}{|c|c|c|c|c|c|c|}
\hline \multirow{2}{*}{ Animals } & \multirow{2}{*}{$\begin{array}{c}\text { Non- } \\
\text { pregnant } \\
\text { (Control) }\end{array}$} & \multicolumn{3}{|c|}{ Month of pregnancy } & \multirow{2}{*}{$\begin{array}{c}\text { At } \\
\text { parturition } \\
1-4 \mathrm{~h} .\end{array}$} & \multirow{2}{*}{$\begin{array}{c}\mathbf{1}^{\text {st }} \text { month } \\
\text { of } \\
\text { lactation }\end{array}$} \\
\hline & & $7^{\text {th }}$ & $8^{\text {th }}$ & $9^{\text {th }}$ & & \\
\hline Heifers & $\begin{array}{c}0.99 \pm 0.12 \\
\mathrm{Ab}\end{array}$ & $\begin{array}{c}0.88 \pm 0.18 \\
\text { Ac }\end{array}$ & $\begin{array}{c}1.02 \pm 0.18 \\
\mathrm{Ab}\end{array}$ & $\begin{array}{c}1.16 \pm 0.12 \\
\mathrm{Aa}\end{array}$ & $\begin{array}{c}0.88 \pm 0.16 \\
\text { Ac }\end{array}$ & $\begin{array}{c}0.89 \pm 0.16 \\
\text { Ac }\end{array}$ \\
\hline $\begin{array}{l}\text { Multiparous } \\
\text { Cows. }\end{array}$ & $\begin{array}{c}1.07 \pm 0.2 \\
\mathrm{Aa}\end{array}$ & $\begin{array}{c}0.93 \pm 0.29 \\
\mathrm{Ab}\end{array}$ & $\begin{array}{c}1.05 \pm 0.24 \\
\mathrm{Aa}\end{array}$ & $\begin{array}{c}1.18 \pm 0.16 \\
\mathrm{Aa}\end{array}$ & $\begin{array}{c}0.74 \pm 0.20 \\
\text { Ac }\end{array}$ & $\begin{array}{c}0.92 \pm 0.15 \\
\mathrm{Ab}\end{array}$ \\
\hline
\end{tabular}

The different small letters refer to significant differences at $(\mathrm{p} \leq 0.05)$ among groups in horizontal row. The different large letters refer to significant differences at $(\mathrm{p} \leq 0.05)$ between groups in vertical column. $\mathbf{n}=$ refer to the number of the animals in each group.

Phys.state refer to physiological state of animals

Table (2) showed that there was a significant increase $(p \leq 0.05)$ of T4 concentration in $9^{\text {th }}$ month pregnant heifers compared with non pregnant control, $7^{\text {th }}, 8^{\text {th }}$, month pregnant, parturient, and first month lactating heifers groups. While no significant $(\mathrm{p} \leq 0.05)$ difference in $\mathrm{T} 4$ values were recorded in parturient and $1^{\text {st }}$ month lactating heifers compared with control group.

The same patterns were observed in cows. No significant difference was observed between both multiparous cows and heifers in all studied groups. 
Table (2): The serum T4 level (ng/ml) of heifers and cows during late pregnancy, parturition, and early lactation. (Mean \pm SD).

\begin{tabular}{|c|c|c|c|c|c|c|}
\hline \multirow{3}{*}{ Phys.state } & \multirow{3}{*}{$\begin{array}{c}\text { Non- } \\
\text { pregnant } \\
\text { (Control) }\end{array}$} & \multirow{2}{*}{\multicolumn{3}{|c|}{ Month of pregnancy }} & \multirow{3}{*}{$\begin{array}{c}\text { At } \\
\text { parturition } \\
1-4 \mathrm{~h} .\end{array}$} & \multirow{3}{*}{$\begin{array}{c}n=6 \\
1^{\text {st }} \text { month } \\
\text { of } \\
\text { lactation }\end{array}$} \\
\hline & & & & & & \\
\hline & & $7^{\text {th }}$ & $8^{\text {th }}$ & $9^{\text {th }}$ & & \\
\hline Heifers & $\begin{array}{c}3.38 \pm 0.5 \\
\text { Ac }\end{array}$ & $\begin{array}{c}5.26 \pm 0.93 \\
\mathrm{Ab}\end{array}$ & $\begin{array}{c}5.67 \pm 0.49 \\
\mathrm{Ab}\end{array}$ & $\begin{array}{c}6.67 \pm 0.48 \\
\mathrm{Aa}\end{array}$ & $\begin{array}{c}3.28 \pm 0.64 \\
\mathrm{Ac}\end{array}$ & $\begin{array}{c}3.65 \pm 0.59 \\
\text { Ac }\end{array}$ \\
\hline $\begin{array}{l}\text { Multiparous } \\
\text { cows. }\end{array}$ & $\begin{array}{c}3.56 \pm 0.65 \\
\mathrm{Ae}\end{array}$ & $\begin{array}{c}5.45 \pm 0.71 \\
\text { Ac }\end{array}$ & $\begin{array}{c}6.08 \pm 0.60 \\
\mathrm{Ab}\end{array}$ & $\begin{array}{c}6.92 \pm 0.30 \\
\mathrm{Aa}\end{array}$ & $\begin{array}{c}3.41 \pm 0.40 \\
\mathrm{Ae}\end{array}$ & $\begin{array}{c}4.30 \pm 0.9 \\
\mathrm{Ad}\end{array}$ \\
\hline
\end{tabular}

The different small letters refer to significant differences at $(\mathrm{p} \leq 0.05)$ among groups in horizontal row. The different large letters refer to significant differences at $(\mathrm{p} \leq 0.05)$ between groups cows in vertical column. $\mathbf{n}=$ refer to the number of the animals in each group Phys. state refer to physiological state of animals

The results indicated that a significant increase $(\mathrm{p} \leq 0.05)$ in cortisol level was recorded in parturient heifers compared with control and other studied groups (Table 3).On other hand no significant difference was observed in cortisol level between $7^{\text {th }}$ month pregnant heifers and control. In cows serum cortisol level was increased significantly $(\mathrm{p} \leq 0.05)$ at parturition compared with control and other studied groups in cows, while a significant decrease $(\mathrm{p} \leq 0.05)$ in cortisol levels were recorded of $7^{\text {th }}$ month, $8^{\text {th }}$ month pregnant and first month lactating cows compared with control and $9^{\text {th }}$ month pregnant cows. In compairison between cows and heifers a significant $(\mathrm{p} \leq 0.05)$ increase in of cortisol levels were observed in control, $8^{\text {th }}$ and $9^{\text {th }}$ month pregnant and parturient groups than that of heifers.

Table (3): The serum cortisol level ( $\mu \mathrm{g} / \mathrm{dl})$ in heifers and cows during late pregnancy, parturition, and early lactation (Mean \pm SD).

\begin{tabular}{|c|c|c|c|c|c|c|}
\hline \multirow{2}{*}{ Phys.state } & \multirow{2}{*}{$\begin{array}{c}\text { Non- } \\
\text { pregnant } \\
\text { (Control) }\end{array}$} & \multicolumn{3}{|c|}{ Month of pregnancy } & \multirow{2}{*}{$\begin{array}{c}\text { At } \\
\text { parturition } \\
1-4 \mathrm{~h} .\end{array}$} & \multirow{2}{*}{$\begin{array}{c}\mathbf{1}^{\text {st }} \text { month } \\
\text { of } \\
\text { lactation }\end{array}$} \\
\hline & & $7^{\text {th }}$ & $8^{\text {th }}$ & $9^{\text {th }}$ & & \\
\hline Heifers & $\begin{array}{c}10.92 \pm 1.03 \\
\mathrm{Bd}\end{array}$ & $\begin{array}{c}10.78 \pm 0.7 \\
\text { Ad }\end{array}$ & $\begin{array}{c}11.82 \pm 0.89 \\
\mathrm{Bc}\end{array}$ & $\begin{array}{c}13.50 \pm 0.84 \\
\mathrm{Bb}\end{array}$ & $\begin{array}{c}14.52 \pm 0.64 \\
\mathrm{Ba}\end{array}$ & $\begin{array}{c}13.82 \pm 1.06 \\
\mathrm{Ab}\end{array}$ \\
\hline $\begin{array}{l}\text { Multiparous } \\
\text { Cows. }\end{array}$ & $\begin{array}{c}15.87 \pm 1.39 \\
\mathrm{Ab}\end{array}$ & $\begin{array}{c}11.43 \pm 0.55 \\
\text { Ad }\end{array}$ & $\begin{array}{c}13.30 \pm 0.67 \\
\text { Ac }\end{array}$ & $\begin{array}{c}15.57 \pm 1.25 \\
\mathrm{Ab}\end{array}$ & $\begin{array}{c}17.20 \pm 1.01 \\
\mathrm{Aa}\end{array}$ & $\begin{array}{c}13.82 \pm 1.95 \\
\text { Ac }\end{array}$ \\
\hline
\end{tabular}

The different small letters refer to significant differences at $(\mathrm{p} \leq 0.05)$ among groups in horizontal row. The different large letters refer to significant differences at $(\mathrm{p} \leq 0.05)$ between groups in vertical column. $\mathbf{n}=$ refer to the number of the animals in each group.

Phys.state refer to physiological state of animals 


\section{Discussion}

The serum levels of thyroxin $\left(\mathrm{T}^{\mathrm{r}}\right)$ and Triiodothyronine $(\mathrm{T} \varepsilon)$ as reported in the Tables (1) and (2) respectively are in agreement with Huszenicza, et al. (2002) who found that high levels of thyroid hormones were recorded in late pregnancy which were followed by a significant decrease in the periparturition period and the level of T4 were found to be lower in the earliest day of lactation than in late lactation in cows.

The values of $\mathrm{T} 3$ found in the present study (Table 1) indicated that T3 level decreased significantly in parturient and first month lactating heifers and cows. These results are corresponded to the findings of Reist et al. (2002) and Pezzy et al (2003) whom reported that the concentrations of thyroid hormones were reduced in the blood of dairy cows in the transitional period, with a markedly declined (T3) in blood shortly before and after calving, which may occurs due to negative energy balance and high lipid mobilization.

The serum T3 levels observed in the present study increased significantly in first month lactating cows compared with parturient cows. The T3 levels are well within the range as has been observed by Liesegang et al. (2006). Cows in postpartum negative energy balance respond to decrease the levels of T3 \& T4 and increase the level of rT3 (Mc Guire et al 1991; Yambayamba et al 1996). At the onset of lactation appears to be a homeostatic adaptation to a decreased food supply, similar to the situation with fasting or energy malnutrition, the plasma concentrations of T3 \& $\mathrm{T} 4$ were in their nadir in the early postpartum days possibly owing to increased metabolic clearance of thyroid hormones in peripheral tissues to suppressed secretary capacity of the thyroid gland .In the supporting the idea also TRH-induce T4\& $\mathrm{T} 3$ responds less pronounced in the second weeks of lactation than before calving or 3 months postpartum (Tveit et al 1990; Huszenicza, et al 2002).

The significant increase of $T^{r} \& T^{\varepsilon}$ levels in the present study during late pregnancy may be occurs due to a high estrogen levels during advanced pregnancy which stimulate production of thyroid hormone-binding globulin, leading to a rise in levels of bound T3\&T4 and simultaneous drop in levels of free T3\&T4, with the drop in thyroidbinding globulin following delivery, levels of T3\&T4 drop (Learoyd et al 1992).

The results of serum cortisol level of multiparous cows and heifers are given in Table 3. The results showed that cortisol concentration during pregnancy reached maximum level at parturition and then declined significantly in first month of lactation. Similarly Hendrick et al. (1998) who found that the serum cortisol levels were increased with parturition approached, with peak levels at parturition, the peak cortisol levels in late pregnancy may be as result of placental production of corticotrophin releasing hormone and fall abruptly at delivery.

The results observed in the present study are also accordance with the findings of Kulberg et al (2002) who reported that serum cortisol levels increased as parturition approached, with peak level at parturition and slightly decreasing levels were found postpartum. Similarly high levels of cortisol were also observed in dairy heifers during the six weeks prior to delivery (Kornmatitsuk et al., 2004).

The significant increase of cortisol level with advanced pregnancy may be occur due to the stress of pregnancy which causes release of adrenocorticotropic hormone from the pituitary gland in late pregnancy, induces synthesis and secretions of glucocorticoids from the adrenal cortex (Kulberg et al., 2002)

\section{References}

Bani Ismail, A.; AL-Zghoul, M.F. and ALAbabneh, O.M. (2009). Serum levels of insulin - like growth factor-I, thyroid hormones and Skeletal Muscle Fiber Size in Castrated Lambs with and without Androgen Treatment. American J. of Applied Sciences 6:518-531.

Hendrick V, M.D.; Lori, L.; Altshuler, M.D and Rita Suri, M.D. (1998). Psychosomatics. 
Academy of Psychosomatics Medcine 39:93-101.

Henze, P.; Bicklardt, K. and Fuhrmann, H.(1994). The influences of insulin, cortisol. Growth hormone and total oestrogen on the pathogenesis of ketosis in sheep. Dtsch Tierarztl Wochenschr, 101; 61-65.

Huszenicza, Gy.; Kulcsar,M. and Rudas,P., (2002). Clinical endocrinology of thyroid gland functions in ruminanats. Vet. Med. Czech, 47(7):199-210.

Iriadam, M. (2007). Variation in certain haematological and biochemical parameters during the peripartum period in Kilis does. Small Ruminant Res.73, 54-57.

Kornmatitsuk, B.; Konigsson, K.; Kindahl, H and Gustafsson, H. (2004). Clinical signs, body temperature, and hormonal changes in dairy heifers after induction of parturition with PGF2. $\square$ 14th) International Congress on Animal Reproduction, Stockholm, 1, p. 179.

Krajnicakova, M.; Kovac, G.; Kostecky, M.; Valocky, I.; Maracek, I.; Šutiakova, I. and Lenhardt, L., (2003). Selected clinical-biochemical 7-182.

Kulberg, S.; Storset, A.K.; Heringstad, B. and Lasen, H.J. (2002). Reduced levels of total leukocytes and Neutrophils in Norwegian cattle selected for decreased mastitis incidence. J. of Dairy Sci.Vol. 85, No.12:3470-3475.

Learoyd, D. L.; Fung, H. Y. M.; and McGregor, A.M.(1992). Postpartum thyroid dysfunction. Thyroid 2:73-80.

Liesegang, A.; Risteli, J., and Wanner, M., (2006). The effects of first gestation and lactation on bone metabolism in dairy goats and milk sheep. In press.Bone,38(6):794802.

McGuire, M.A.; Beede, D.K.; Collier, R.J.; Buonomo,F.C.; Delornzo, M.A. and Wilcox,C.J.(1991). Effects of acute thermal stress and amount of feed intake on concentrations of somatotropin insuline- like groth factor (IGF-1_ and IGF-11, and thyroid hormones in plasma of lactating Holestin cows. J.Anim.Sci. 69: 2050-2056.

Nikolić J.A.; Samanc, H.; Begović, P.; Damjanović, Z.; Djoković, R.; Kostić, G.; Krsmanović, J.; Resanović ,V. (1997): Low peripheral serum thyroid hormone status independently affects the hormone profile of healthy and ketotic cows during the first week postpartum Acta. Vet. Beograd, 47: 3-13.

Pezzy, C.; Accorsi, P.A.; Vigo, D.; Govani, N. and Gaiani, R. (2003). 5'-Deiodinase activity and circulating thyronines in lactating cows. J Dairy Sci 86: 152-158.

Reist, M.; Erdin, D.; Von Euw, D.; Tschuemperlin, K.; Leunberger, H.; Chilliard, H.; Hammon,M.; Morel,C.; Philopona, C.; Zbinder,Y.; Kuenzi, N. and Blum, J.,W.( 2002). Estimation of energy balance at the individual and herd level using blood and milk traits in highyielding dairy cows. J Dairy Sci 85:33143327.

Slanina, L. (1977). Zdravie a chorobonst teliet $\mathrm{v}$ priemyselnej produkcii.Pviroda, Bratislava, 335.

Steel, R. and Torrie, J. (1980). Principle and procedures of statistic, A biometric callab roach., 2nd ed. Edited by: Rabbin ,A.

Turk,R.; Juretic, D.; Geres, D; Turk, N.; Rekic, B.; Simeon-Rudolf, V. Robic, M. and Svetina, A.(2005). Serum paraoxonase activity in dairy cows during pregnancy. Res. Vet. Sci. 79(1): 15-18.

Tveit, B.; Lingaas, F.and Standal, N. (1990). thyroid function in heifers measured by hormone levels before and after injection of thyrotropin releasing hormone. Effect of parturition Acta Agric. Scand., 40, 183188.

Yambayamb, E.S.K.; Price, M.A. and Foxcroft, G.R.(1996).Hormonal status, metabolic changes, and resting metabolic rate in beef heifers undergoing compersantory growth. J.Anim.Sci., 74:57-69. 